\title{
MOTHERS AND DAUGHTERS
}

\author{
Sheila Turcon \\ Hamilton, oN, Canada
}

Leslie Minturn Allison. Mildred Minturn: a Biography. Ste-Anne-de-Bellevue, Quebec: Shoreline, 1995. Pp. 192. C\$18.95 (paper).

T eslie Allison has written a loving and compelling portrait of her mother, Lildred Minturn Scott, who died when Leslie was only ten years old. This biography was only made possible because of the survival of letters 
between Mildred and her own mother, Susanna Shaw Minturn, as well as many other family members and friends, and of her diaries. At the outset, I must admit that I play a small role in the birth of this book. In 1983 I was employed at the Russell Project with one of my duties being the locating of new Russell letters. My letter to Leslie Allison inquiring whether any of Russell's letters survived arrived fortuitousty. There were letters and diaries in the attic of her brother-in-law's house, then just months away from being sold. Leslie and I eventually became friends and I encouraged her to have this book published - an amazing achievement for a woman then in her 70 .

Mildred Minturn was born on 19 November 1875 into a wealthy and distinguished New York family who had made their money in shipping, the youngest of four beautiful sisters, separated in age over a ten-year span, and three brothers. Her uncle, Col. Robert Gould Shaw, was the commander of the all-black regiment in the Civil War whose story came to the screen in the 1989 film Glory. Her oldest sister, May, married Henry Dwight Sedgwick, author and brother of Atlantic Monthly editor, Ellery Sedgwick. The two middle sisters were Edith, who married Isaac Newton Phelps Stokes, the architect, and Gertrude, who married Amos Pinchot (who initially was attracted to Mildred), and became the chair of the Women's Peace Party during World War I. There are two photographs of the lovely and elegant sisters on page 48 , one of several black and white illustrations.

Mildred's life is worth learning about, not simply because of her family or the famous people she came in contact with-in addition to Bertrand Russell they included Rodin and Axel Munthe-but because she is representative of the first-wave of college-educated women who graduated in the 1890 s to a world not really ready to receive them from families reluctant to let them go. Marriage was still the preferred path to follow, yet for many of these college graduates, a path they chose either not to follow or were not asked to join. After college, they were left in a state of limbo.

Mildred's writing talents and powers of observation first emerged in a diary she kept at the age of fifteen during an I891 tour of Europe (p. 33). Her father was already dead in 1889 at the relatively young age of 53 and the trip abroad taken with her mother who clung to Mildred as her youngest and, after 1900, only unmarried daughter was the first of many trips mother and daughter would take together.

After attending Brearley School, Mildred enrolled at Bryn Mawr in 1893.

In addition to this book, Leslie also wrote three short pieces for the Bertrand Russell Archives: a portrait of Alys Russell titled "At Aunty Loo's" and "A Visit to I Tatti" (both in RA Rec. Acq. 882); and an untitled piece on her visit, accompanied by Roy Randall, to Beacon Hill School in 1934 to visit Dora Russell (in Rec. Acq. 8II)
For the first time she was "living in close contact with people who were entirely congenial, intellectually her peers, and endlessly stimulating" (p. 45). It was at Bryn Mawr that she met Francis (Kleine) Fincke, who became her closest friend and who would later marry Judge Learned Hand. The Minturn family spent summers together at Murray Bay (La Malbaie) on the north shore of the St. Lawrence river in Quebec where they has vacationed since the late $1880{ }^{2}{ }^{2}$ and it was there that Hand proposed. It was also at Bryn Mawr that Mildred first met Bertrand Russell; she was 2I, he 24. Accompanied by his wife Alys, the two Russells took Bryn Mawr by storm with Mildred becoming one of Alys' targets in her "Revolt of the Daughters" campaign. ${ }^{3}$ The meeting marked a turning-point in Mildred's life as the intelligent and privileged young woman became convinced under the tutelage of the Russells of the fairness of socialism to meet society's needs.

After graduation, Mildred experienced her first bout of serious illness. For this pioneering generation of college women, career paths were limited. Although interested in teaching, Mildred was forbidden to work by her mother, who decreed that she remain at home as her companion. The illness which plagued her on and off for the rest of her life was perhaps coincidental but likely not. The next few years were interspersed with periods of illness (never properly diagnosed but characterized by severe headaches), trips to Europe, and summers at Murray Bay and other haunts of the rich such as Hot Springs, Virginia, and continued study. In 1897-98 Mildred took courses in sociology at Barnard College. ${ }^{4}$ The trips to Europe involved meeting with the Russells both in England and Europe. In the summer of I9OI while in England, she was drawn into the Russells' circle of friends. According to Mildred, the Russells played a type of parlour game, posing a series of questions to guests which were supposed to reveal character. In her diary she wrote rather pithily about them:

${ }^{2}$ An excellent reference book is Charlevoix: Two Centuries at Murray Bay by Philippe Dubé (Kingston and Montreal: McGill-Queen's U. P., 1990). It contains photographs of the Minturns and their homes as well as architectural plans. Susanna Shaw Minturn was the first American woman to have a home built on the riverbank which acted as a catalyst in the establishment of the American colony there. Henry Dwight Sedgwick also writes about Murray Bay in his Memoirs of an Epicurean (New York: Bobbs-Merrill, 1942). Lucy Donnelly and Edith Russell vacationed there.

Hand's visit to Murray Bay and his proposal in August $190 \mathrm{I}$ is described in Gerald Gunther, Learned Hand: the Man and the Judge (New York: Knopf, 1994), pp. 77-8.

Alys Russell, "A Reply from the Daughters," Nineteenth Century, 35 (March 1894): 443-50. She begins her article by calling for a revolt by daughters whom she characterizes as "proverbially dutiful".

${ }^{4}$ This information is contained not in the book but in a brief biographical chronology that Leslie Allison prepared for the Russell Archives (Rec. Acq. 805). 
[On Beatrice Webb:] I never shall forget Mrs. Webb laying bare her soul before us all, looking awfully handsome, her dark face flushed with excitement, slouched back in a big chair by the fire, smoking cigarette after cigarette, her bright black eyes snapping as she brought out one surprising confession after another.

[On Philip Morrell:] a splendid young Englishman of the broad-shouldered exquisitely dressed type that I had expected to find growing on every bush.

[On the Berensons:] Mrs. Berenson is charming, big and fair and kind... If she had chosen to live with her little white rat of a husband before she was free to marry him it seemed to me a most private matter of their concern. (Pp. 89-90)

Later that year Mildred met up again with the Russells, accompanied by the Whiteheads, in Venice. If something was amiss with this quartet just a few months before the Russells' marriage would break down, Mildred did not notice it. At a dinner party, the topic of discussion was the "meaning of greatness" (p. 90). She also noted in her diary that "Bertie has a genius for definition ... he raps out some wonderfully smart things every time and often something with really deep meaning" (p. 9I). Mildred's friend Kleine did not share Mildred's enthusiasm, writing on Christmas day, 19o: "Well she [Alys] is a dear but don't ... let that horrid little Bertie man talk much to you." Alys, herself, summed up Mrs. Minturn as a amusing tyrant to her own mother in a letter of 4 September, noting that she had been thanked by the old lady for providing intellectual companionship for Mildred which she equated with her other daughters' love of dresses (Gertrude) or free kindergartens (May) (p. 9I).

In 1903 Mildred, finally, at the age of 27 , got away from home by taking up residence in Paris in order to be treated by Dr. Gorodichze, who specialized in nervous disorders. She, of course, did not live alone but first with Anna Osgood, a family friend. It is easy to see parallels between Mildred and Lady Ottoline Morrell who seems to have suffered from similar maladies. In 1904 Mildred was rejoined by her mother, and the two women took a cottage in Surrey for the summer in order to be near the Russells. During her sojourn in Paris, Mildred had embarked on translating into English some of the writings of the French socialist Jean Jaurès whom she clearly admired.' She took long walks with Russell, as she had at Bryn Mawr (p. 62), as well as dining with both Russells twice a week, accompanied by her mother. Leslie

5 Jaurès (1859-1914) was a writer, orator, and politician. He served in the French Chamber of Deputies in $1885-89,1893-98$, and $1902-14$. He helped found the French socialist paper L'Humanité, and wrote the eight-volume Socialist History of the French Revolution (1901-07). He was assassinated in I91
Allison makes use of Russell's letters to Lucy Donnelly in which he often expresses a negative opinion of Mildred, on one occasion calling her "shallow and frivolous" (p. 108). Mildred remained unaware of any negative feelings toward her. Back in Paris in 1905 Mildred attended lectures at the Ecole de Droit on Workingmen's Insurance and continued her work on Jaurès. It was not until then that she actually met him, describing the visit to her mother, who had returned to America, in a letter of 26 January 1905. Her remarks illustrate clearly the difference between theory and practice: "He was as satisfactory as possible ... talked humanly and interestingly—a simple dirty bourgeois in a dreadful suburban little house."

The summer of 1905 saw her back in England again, this time en route to Murray Bay. At a luncheon party she met Ottoline Morrell - "a wonderful elongated aesthetic lady ... who talked very intensely about life in general ... [while appearing to be] wrapped up in a old window-curtain." She also stayed at Bagley Wood, which:

... Alys has made ... so liveable and charming. Bertie knew nothing of it between the time when they chose the site last August and the day he came back from a walkingtour to find his clothes in the bureau drawers and his books on the shelves. (P. 138 )

She stopped again on her way back to Paris, socializing with them and the "perfectly charming" G. Lowes Dickinson, meeting with Ramsay MacDonald over the Jaurès book, ${ }^{6}$ and attending Shaw's play, Major Barbara. After the play, Alys took her to a tea at the Bank of England, hosted by Una Birch (later Pope-Hennessy) whose father was a bank officer, and attended by Yeats, Lady Gregory, J. M. Synge, and Desmond MacCarthy among others (p. I49). The following year, the Russells stopped to see her in Paris, bringing along Santayana. It was shortly after that visit that she met her future husband, Arthur Scott, the nephew of the Manchester Guardian editor, C. P. Scott.

With the completion of her work on Jaurès, Mildred turned her attention

${ }^{6}$ Mildred discussed her translation with Ramsey Macdonald in 1904 and 1905 when she was in England. He appears to have agreed to publish part of her introduction in his Socialism and Society (1905) and pressed her to ger all of it published in America (pp. 136, 139-40). In this she was successful, an accomplishment that Allison did not discover. Mildred's book, Studies in Socialism, was published in New York and London by G. P. Putnam's Sons in 1906. In 1970 Kraus Reprint Co. of New York reprinted it. It contains a 38-page introduction which summarizes socialist theories for an American audience and concludes with a brief biographical sketch of Jaurès. The articles that Minturn translates were first published in L'Humanité, a socialist daily paper, in Paris: she replaces three arricles that concern the Napoleonic code with three more ilely to intest Ameres Soly in Macdonald's book Socialism and Society makes no reference to Mildred Minturn. 
to an investigation of co-operative societies. Her social life never abated despite her intellectual pursuits. She had broken with her therapist, Gorodichze, over his refusal to treat a financially poor friend of hers for free and was now being treated by Pierre Janet. Although Mildred had no money problems of her own, it seems unlikely she had control over any capital. Into this busy schedule she was able to fit a visit with Rodin at his villa in Meudon. Her diary contains several quotations from Rodin's conversation.

On what was now becoming an annual visit, the summer of 1906 saw her gain visiting the Russells. Russell met the news of her engagement and subsequent marriage in New York in the autumn of 1906 with less than enthusiasm. He thought the marriage would be all right for Mildred but probably not happy, noting to Lucy Donnelly that marriages seldom were (p. 174). Leslie Allison's narrative, which deftly knits together letters and diaries fashion a fascinating story of a life, ends with the marriage. At this point in the book I would have placed Allison's account titled "A Child's Eye View" which appears at the front of the book and describes her memories of her mother and her childhood. Instead we get the epilogue by her niece (ursula Birkett) which summarizes very nicely events from 1906 until Mildred's death from cancer in $1922 .{ }^{7}$ It does an excellent job of what it is intended to do but it does not nor cannot match in tone or detail what has come before. Mildred never built on the intellectual work she began with her studies of socialism; she was, however, active in anti-war work during World War I. Motherhood and a marriage which became increasingly more difficult and troublesome consumed her.

The book concludes with Mildred's letter to her three children, Leslie, her older sister, Honor, and younger brother, Russell, ${ }^{8}$ written one month before her death. Leslie Allison did not read this letter until I992: "Know that I am going to try to stay as near to you as I can until you are grown up. I believe that very great love holds souls near to the people they love, if they want to stay" (p. 190). A mother's wish did in the end come true, as Leslie in old age found again her mother's love which during the intervening years she had doubted. She also found a woman whom she greatly admired and was proud to be called her daughter.

7 There are thirteen letters extant from Russell to Mildred Minturn for this period; copies of the letters are in the Russell Archives. It was not lack of material that brought an abrupt end to the biography in 1906. Rather Leslie Allison found the task too emotionally daunting to continue.

${ }^{8}$ Bertrand Russell was Russell Scott's godfather. In a letter of In January 1917, Russell apologizes for not having a suitable gift for his namesake (Rec. Acq. 805). 